\title{
TREE PESTS: SOME RECENT ARRIVALS IN NEW ZEALAND
}

\author{
K.J. FROUD, J.G. CHARLES and D.J. ALLAN \\ HortResearch, Private Bag 92169, Auckland
}

\begin{abstract}
New insects continue to establish in New Zealand from accidental introductions. The Mediterranean fruit-fly, white-spotted tussock moth and willow sawfly are the most well publicised recent arrivals. However, several other tree pests of note have also arrived recently in Auckland. Ash whitefly Siphoninus phillyreae (Haliday) (Homoptera: Aleyrodidae) was found in May 1995, and now occurs throughout the Auckland region, and south at least as far as Hamilton. The pest status of ash whitefly has been limited by the arrival of Encarsia inaron, a specific parasitoid that presumably entered New Zealand with its host. The brown lace lerp (Cardiaspina fiscella) (Homoptera: Psyllidae) arrived from Australia in May 1996 and is now present throughout Auckland. It attacks six species of Eucalyptus including two species of economic importance. In May 1997, Ctenarytaina sp. (Homoptera: Psyllidae) was found attacking Acmena smithii trees, feeding predominantly on new shoots and leaves while creating large amounts of honeydew and reducing plant vigour. It is now widespread throughout Auckland. Three other new pests of minor economic importance include Dicranosterna semipuntata (the Acacia tortoise beetle), and two more psyllids, Eucalyptolyma maideni (spotted gum psyllid) and Cryptoneossa triangula, both pests of Eucalyptus spp.
\end{abstract}

\section{AUSTRALIAN BLACK BEETLE ADORYPHORUS COULONI (BURMEISTER) EXTENDS ITS RANGE ON BANKS PENINSULA}

\author{
M.J. GORTON ${ }^{1}$, R.B. CHAPMAN ${ }^{1}$ and R.J. TOWNSEND ${ }^{2}$ \\ ${ }^{1}$ Soil, Plant and Ecological Sciences Division, P.O. Box 84, Lincoln University \\ ${ }^{2}$ AgResearch, P.O. Box 60, Lincoln
}

Australian black beetle, Adoryphorus couloni, was first identified from specimens collected at Heathcote Valley, Banks Peninsula in 1963. Several surveys since then showed that the species had spread to occupy at least 3000 ha of pasture land on Banks Peninsula. A survey covering approximately 9600 ha of Banks Peninsula was conducted during summer 1997-98. The results showed that a further 1500 ha of previously uninfested land has now been colonised. The majority of spread has occurred towards the southwest end of Lyttleton Harbour and invasion of the Canterbury Plains side of Banks Peninsula has occurred through Gebbies Pass. Approximately 5600 ha is now known to be infested by Australian black beetle. Using previous survey data and the results of this survey, the rate of spread was estimated using a simple dispersal model. The rate of dispersal was estimated to be $1.14 \mathrm{~km}$ per year. The impact of this pest on pasture still remains to be determined. 